https://idp.uoc.edu

ARTICLE

\title{
Europe facing the digital challenge: obstacles and solutions
}

\author{
David Ramiro Troitiño \\ Tallinn University of Technology (TalTech) \\ Tanel Kerikmäe \\ Tallinn University of Technology (TalTech)
}

The subject of digital development in the EU is at a crucial moment for its future. New technologies have been developed and are changing the way in which the European institutions interact with the citizens, the Member States and the international world. Therefore, the European Union must adapt fast and efficiently to the new possibilities to respond to its internal and external necessities generated by the digital revolution. It is a controversial field in terms of integration because originally it was was not included in the European Union Treaties. It was a primitive field that needed further development to reach the current relevance. This situation generates tensions within the Member States because normally they are reluctant to further cession of national sovereignty unless the necessity is manifest.

Nevertheless, the novelty of the topic provides a great advantage; most of the Member States of the European Union have not legislated on this field or have done it mildly. This reduces the conflicts between national and European legislation, as the possibilities of conflict are minimal due to lax national approaches or even non-existing national legislations. Consequently, the European Union is facing a challenge that will define Europe in the coming decades in many different perspectives.

David Ramiro Troitiño treats the developments and impacts of the digital revolution over the citizens and economy of Europe. He focusses on the European Digital Single Market, among other initiatives, which will obviously have a substantial influence on economic relations between its members and in the world, as the European market still occupies a central role in the world commerce system. His research focuses on the analysis of European developments around digital initiatives and their influence on the own essence of the organisation. The impact of this process will define the European Union in the 21st century. Sander Sagar and Thomas Hoffmann complement the vision related with the EU Digital Single Market from a legal perspective based on the directives aiming at their actual implementation, providing a legal frame for safe development. 
The European Union cannot slow down the fast technological developments and its implementation in our society because of bureaucratic barriers; innovation is the key for success. Therefore, Olga Shumilo and Tanel Kerikmäe explore the European position on Artificial Intelligence from a perspective based on the mentioned premises. Their research provides a valuable insight of the obstacles for innovation and the resistance to change generated by rigid civil service.

The European Union in particular, and Europe in general is united regarding human rights. The European values are a key factor in the integration of the continent because they provide the communality required to a process based on common interest and common necessities. Hence, the protection of the European values, especially human rights, is a priority for the European Union. The Artificial Intelligence field requires a legal frame to respect, and even foster, the European values. It requires a European approach to protect the European citizens and respect the European way of life. Pablo Martínez Ramil develops the topic from a new perspective based on legal aspects. Ethics are part of these European values, and have an impact on the use to be made on the possibilities offered by new technologies. The European Union is working on facial recognition and privacy, establishing borders defining our societies for the coming decades. It is a topic researched by Archil Chochia and Teele Nässi in this dossier. The data provided by the digital capacities and their use is a main concern in the European Union. Jozef Andraško - Ondrej Hamulák - Matúš Mesarčík focus their research on governance aspects of cooperative, connected and automated mobility, providing a vision of the EU strategy in such a sensitive field.

The digital development has created new possibilities, but also new necessities that need to be properly addressed to protect the European Union, its Member States, and its citizens. The most notorious is Cyber security and EU cyber-diplomacy. Virtual threats are already a reality, as internal and external agents are using them against the European Union. As an example, the development of internal terrorism has been fostered by the new technological possibilities of propaganda and dissemination. New common actions are required to fight against an internal threat. In addition, external forces are influencing the European Union affairs by digital means, such as the spread of fake news or the use of technology to gain a competitive advantage internationally. Agnes Kasper, Anna-Maria Osula and Anna Molnár treat this complex topic from a brilliant approach combining real politics and new technological necessities.

Therefore, the combination of these research articles provides a comprehensive vision of the digital challenges to the European Union. A global vision providing a general approach to a topic that will define the future of Europe, and the world, in the coming years. 


\title{
References
}

HAMUL'ÁK, O. (2016). National sovereignty in the European Union: View from the Czech perspective. Springer. DOI: https://doi.org/10.1007/978-3-319-45351-4

HOFFMANN, T.; PRAUSE, G. (2018). "On the regulatory framework for last-mile delivery robots". In: Machines, vol. 6, no. 3, p. 33. DOI: https://doi.org/10.3390/machines6030033

JOAMETS, K.; CHOCHIA, A. (2020). "Artificial Intelligence and Its Impact on Labour Relations in Estonia". In: Slovak Journal of Political Sciences, vol. 20, no. 2, pp. 255-277. DOI: https://doi.org/10.34135/ sjps.200204

KASPER, A.; VERNYGORA, V. A. (2020). Towards a 'cyber Maastricht': Two steps forward, one step back. RAMIRO TROITIÑO, D.; KERIKMÄE, T.; DE LA GUARDIA, R.; PÉREZ SÁNCHEZ, G. (eds). The EU in the 21st Century. Cham: Springer. DOI: https://doi.org/10.1007/978-3-030-38399-2_12

\section{Recommended citation}

RAMIRO TROITIÑO, David; KERIKMÄE, Tanel (2021). "Europe facing the digital challenge: obstacles and solutions". IDP. Internet, Law and Politics E-Journal. No. 34. UOC [Accessed: dd/mm/aa] http://dx.doi.org/10.7238/idp.v0i34.393310

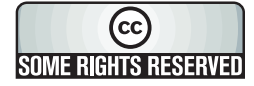

The texts published in this journal, unless otherwise indicated, are subject to a Creative Commons Attribution No Derivative Works 3.0 Spain licence. They may be copied, distributed and broadcast provided the the author, the journal and the institution that publishes them (IDP. Revista de Internet, Derecho y Política; UOC) are cited. Derivative works are not permitted. The full licence can be consulted on http://creativecommons.org/licenses/bynd/3.0/es/deed.es.

\author{
About the authors \\ David Ramiro Troitiño \\ Tallinn University of Technology (TalTech) \\ david.troitino@taltech.ee \\ ORCID: https://orcid.org/0000-0002-0542-5724 \\ Tanel Kerikmäe \\ Tallinn University of Technology (TalTech) \\ tanel.kerikmae@taltech.ee \\ ORCID: https://orcid.org/0000-0002-5972-827X
}

Universitat

Oberta

de Catalunya 